\section{Early-life socioeconomic status and malocclusion in adolescents and young adults in Uruguay}

\author{
Estatus socioeconómico durante la primera \\ infancia y maloclusión en adolescentes y adultos \\ jóvenes en Uruguay
}

\author{
Nível socioeconômico na primeira infância e \\ oclusopatia em adolescentes e adultos jovens \\ no Uruguai
}

\author{
Marília Leão Goettems 1 \\ Mariana Ourens 2 \\ Laura Cosetti 2 \\ Susana Lorenzo 2 \\ Ramon Álvarez-Vaz 2 \\ Roger Keller Celeste 3
}

\begin{abstract}
This study aims to estimate orthodontic treatment need among 15-24 year-old individuals in Montevideo, Uruguay, and the association of occlusal traits with demographic, clinical and socioeconomic factors, considering a life course approach. A cross-sectional study using data from the First National Oral Health Survey in Uruguay was conducted. A two-stage cluster procedure was used to select a sample of 278 individuals in Montevideo. Household interviews and oral examinations were performed by six dentists. Dental Aesthetic (DAI) and Decayed Missing and Filled Teeth Indices (DMFT) were used to assess orthodontic treatment need and dental caries, respectively. Early life and current socioeconomic factors were obtained from the interview. Ordinal logistic regression was used to model the DAI index. Prevalence of definite malocclusion was 20.6\%, followed by severe (8.2\%) and very severe (7.6\%). In the adjusted analysis, individuals with untreated dental caries $(O R=1.11$; 95\%CI: 1.03-1.20) and those who reported a lower socioeconomic level at 6 years of age $(O R=5.52$; 95\%CI: 1.06-28.62) had a higher chance of being a worse case of malocclusion. Current socioeconomic position was not associated with orthodontic treatment need. Individuals aged 22-24 years $(O R=$ 1.59; 95\%CI: 1.05-2.41) had a lower chance than those aged 14-17. This study shows that orthodontic treatment need is relatively high in Uruguayan adolescents and young adults. There is a potential relationship between early life socioeconomic status and the occurrence of malocclusion in adolescents and young adults under a life course approach.
\end{abstract}

Malocclusion; Dental Caries; Dentistry

\section{Correspondence}

M. L. Goettems

Faculdade de Odontologia, Universidade Federal de Pelotas. Rua Gonçalves Chaves 457, Pelotas, RS 96015-000, Brasil. mariliagoettems@hotmail.com

1 Faculdade de Odontologia, Universidade Federal de Pelotas, Pelotas, Brasil.

2 Facultad de Odontología, Universidad de la República, Montevideo, Uruguay.

3 Faculdade de Odontologia, Universidade Federal do Rio Grande do Sul, Porto Alegre, Brasil. 


\section{Introduction}

Malocclusion is associated not only with functional and/or aesthetic consequences, but also with psychosocial consequences, especially in adolescents 1,2 . The presence of malocclusion can affect the well-being of individuals 3 and its treatment is associated with improvements in quality of life 4,5 . Although occlusal status is mainly determined genetically 6 , variations in occlusion and development of muscles and jawbones are influenced by environmental factors 7 , including harmful habits at childhood 8 and oral health status (dental caries). There is evidence that children from lower socioeconomic background may adopt more often deleterious oral habits associated with malocclusion, including thumb sucking and pacifier use 9, nursing bottle, mouth breathing and onicophagia 10. Moreover, children from less educated mothers may have earlier exclusive breastfeeding abandonment 11, which is associated with malocclusion in primary dentition 12 . The occurrence of malocclusion in primary dentition is predictive for malocclusion in the permanent dentition 13, especially when there is late discontinuing of deleterious habits 14. A study with adolescents in Brazil showed that severe or very severe malocclusion was more prevalent among socially disadvantaged adolescents, with reported harmful habits 15 .

Although socioeconomic factors in adult life seems to be weakly or not associated with malocclusions $16,17,18$, there is no evidence if early life socioeconomic conditions and socioeconomic trajectories during the life-course could influence the development of malocclusion. Life-course epidemiology focus on elucidating effects of early exposures on health ${ }^{19}$. Regarding occlusal status, it is possible that the socioeconomic trajectory determines exposure to predisposing factors for malocclusion, including the adoption of harmful habits, poorer oral health, and lower access to preventive appointments and early treatment. This knowledge can help to elucidate factors associated with malocclusion and thereby indicate the most appropriate time for preventive interventions 20 .

Whereas prevalence and consequences of malocclusion have been studied worldwide 21,22, few information about prevalence of malocclusions and orthodontic treatment needs are available in Uruguay. The First National Oral Health Survey (2010-2011) showed a 33.8\% prevalence of orthodontic treatment need among adolescents and young adults on the countryside, and $8.5 \%$ of them presented severe malocclusion 23. This study used data from the First National Oral Health Survey to estimate orthodontic treatment need among 15-24 year-old individuals in Montevideo, the capital of Uruguay, and to test the association between occlusal traits and demographic, clinical and socioeconomic factors, considering a life course approach.

\section{Materials and methods}

\section{Design, settings and population}

This cross-sectional study was based on data from the First National Oral Health Survey in Young and Adult Uruguayan Population, conducted by the Faculty of Dentistry, University of the Republic, between August 2010 and December 2011. This survey was conducted with 1,485 participants from the capital Montevideo and 18 administrative departments, including different age ranges. Details about sample size and sampling procedures can be found elsewhere 24 . In this study, the target population was individuals aged 15-24 years living in Montevideo.

\section{Sample size and sampling strategy}

A stratified multiphase cluster sampling design was adopted and carried out by the Uruguayan National Statistics Institute (INE). Sample size calculation was performed to obtain representative subsamples for two regions, the capital and the countryside, and for three age groups: 15-24, 35-44, 65-74 years. The INE used simple randomization to select a subsample from the continuous household survey, which is a larger representative survey used for other studies and for which INE has information about addresses and demographic characteristics. The capital (Montevideo) and all other provinces were considered in two independent samples: one for the provinces and another for the 
capital. We used only the sample of the capital with 15-24 years, which was calculated to estimate $54 \%$ prevalence for periodontal disease, identified in the Brazilian Oral Health Survey (2003) 25, with the Community Periodontal Index, and was estimated for 715 individuals in Montevideo.

Nonetheless, due to logistic constrains, a simple random sub-sample of 357 individuals had to be draw. The calculation considered a type I error of $5 \%$, a power of $80 \%$ and a design effect of 1.5 , and added $20 \%$ for non-responses. The continuous household survey used to generate the current sample is a multistage stratified cluster survey where the final sampling units are the households. The latter is considered the first sampling phase with individuals as second phase of sampling. Sampling weights were calculated and calibrated by statisticians, based on sex and age distribution of the original population to account for non-response.

\section{Data collection}

Data was collected at households and included an interview with closed-ended questions, and oral clinical examination. The interview addressed demographic and socioeconomic characteristics. The survey in Montevideo also included information about socioeconomic trajectory. Oral examination included malocclusion and dental caries following World Health Organization criteria 26. Six dentists previously trained and calibrated conducted examinations, accompanied by assistants. The calibration process included theoretical activities, diagnosis using photographic images and clinical diagnosis compared to a gold standard examiner. For dental caries, inter-examiner kappa values ranged from 0.63 to 0.87 and intra-examiner kappa values ranged from 0.67 to 0.98 . For the Dental Aesthetic Index (DAI), Inter-examiner correlation coefficient ranged from 0.7 and 1.0 and the intra-examiner from 0.6 and 1.0.

\section{Outcome variable}

DAI 26 was used to assess orthodontic treatment need. This index includes the evaluation of the following characteristics: crowding of incisors (0: no crowding; 1: crowded in 1 or 2 segments), spacing in the incisors region ( 0 : no spacing; 1 : spaced at 1 or 2 segments), diastema (0: diastema or 1: $>0 \mathrm{~mm}$ ), mandibular irregularity (0: irregularity of $0-1 \mathrm{~mm}$ or $1: \geq 2 \mathrm{~mm}$ ), maxillary irregularity (0: irregularity of $0-1 \mathrm{~mm}$ or $1: \geq 2 \mathrm{~mm}$ ), overjet, (0: overjet $\leq 0 \mathrm{~mm}, 1:<3 \mathrm{~mm}$ or $2: \geq 3 \mathrm{~mm}$ ), anterior open bite (0: no open bite or $1: \geq 1 \mathrm{~mm}$ ), and number of anterior teeth loss. Measurements were made using WHO periodontal probes and expressed in millimetres. DAI score is calculated by adding the scores of malocclusion traits; it has cut-off points in its scale to define four severity levels and those levels have been shown to be close to clinical diagnosis of orthodontists. DAI scores up to 25 represent normal conditions or mild malocclusions that do not need treatment. DAI scores between 26 and 30 refer to defined malocclusions of elective treatment. DAI scores between 30 and 35 represent severe malocclusions and treatment is highly desirable. DAI scores 36 or higher include very severe or handicapping malocclusions requiring mandatory treatment 27 .

\section{Independent variables}

The independent variables of our study were: sex (male, female); age (14-17, 18-21 and 22-24 years); socioeconomic level; perception of socioeconomic trajectory, and presence of untreated dental caries. The current socioeconomic level was assessed with the Socioeconomic Index, developed by INE and validated by the Faculty of Social Sciences (University of the Republic) 28. Families were classified into one of three strata (low, medium or high) 29 , according to the following characteristics: occupation of the head of the household (1), at least one member of the family whit tertiary education (2), number of income earners (3), household assets and housing characteristics (4), refrigerator with freezer (5), color television (6), car (7), international credit card (8), and number of bathrooms in the house (9). Each variable has a different weight, occupation of the head of the household and number of income earners being the main determinants of the score.

The participants' socioeconomic trajectory was evaluated by two questions - what was the socioeconomic situation of the family when the interviewed was six years old, with the following options: 
very high, high, medium (not poor) low, and very low (poor); and the same question but at the time of the interview. Then the socioeconomic trajectory was classified by unifying the two questions into (1) never poor, (2) from poor to non-poor, (3) from non-poor to poor; and (4) always poor. In addition, the mother's educational level when the respondent was 6 years old was asked and categorized as incomplete elementary school or less, and complete elementary school or more, which in Uruguay corresponds to six years of study.

Dental caries was assessed using the decayed, missing and filled teeth according to the World Health Organization Survey Methods 26. Dental caries was present if individuals had one or more teeth with untreated carious lesions.

\section{Statistical analyses}

The descriptive analysis was presented in frequency tables. The association between the dependent variable (DAI categories) and the occlusal traits with independent variables was tested using the Chisquare test for heterogeneity with Taylor linearization. Ordinal Logistic Regression was used in data analysis, since the outcome is an ordinal variable and this procedure does not require an arbitrary cut-off point, as does the ordinary logistic regression. The proportional odds model was fitted and it estimates the risk of moving to the next higher category of outcome with the increase of one unit of the independent variable. The model did not violate proportional odds assumption, evaluated by Brand Test. Variables presenting a p-value $<0.30$ were included in the multivariate analysis and were retained if they had a p-value $<0.05$ or if a category of the independent variable was significant after adjustment, except for sex and age, which were maintained in the model regardless of their p-value. Multicollinearity was tested and highly correlated predictors were removed. The level of significance was set at 5\% ( $\mathrm{p} \leq 0.05)$. Statistical analyses were done in Stata 14.0 (StataCorp LP, College Station, USA), using the "svy" command from complex samples, considering sampling weights to allow for the design effect on the sample procedure.

The Survey was approved by the Research Ethics Committee of the Faculty of Dentistry of the University of the Republic, according to the standards of the country. A free and informed consent form was read by the examiner, and signed by participants. The participants were informed of their health condition and referred to the Faculty of Dentistry if necessary.

\section{Results}

Our response rate was $78 \%$ and, considering only those for whom the full questionnaire was applied, the final sample for current analyses was 278 individuals aged 15-24 years old. The sample achieved had 59\% power to assess factors associated with malocclusion: 49.2\% (95\%CI: 42.8-57.2) were male and 41.4\% (95\%CI: 35.4-48.0) were from families of low socioeconomic level. A total of 76.9\% (95\%CI: 71.2-81.8) had at least one teeth affected by dental caries and mean DMFT was 3.60 (DT = 1.36; $\mathrm{MT}=0.78 ; \mathrm{FT}=1.46$ ). The DAI ranged from 13 to 53 (mean $24.4 \pm \mathrm{SD}: 7.02$ ). DAI scores of 26 or higher were detected in $36.4 \%$ of the sample. Normal occlusal condition was detected in $82.7 \%$ of participants who had high socioeconomic status at age six and in $57.3 \%$ of participants with low socioeconomic status. The distribution according to the categories showed that individuals with dental caries tended to present higher DAI scores (Table 1).

Table 2 shows the crude and adjusted odds ratios from ordinal regression analysis. In the crude analysis, individuals aged 22-24 years had an odds ratio of 0.45 (95\%CI: 0.24-0.84) in comparison with those aged 14-17 years. Being always poor from 6 to 15-24 years was associated with a 2.36-fold (95\%CI: 1.09-5.11) higher odds of having a worse DAI category in relation to those who were never poor. Adolescents and young adults whose mothers did not complete elementary school presented odds ratio of 1.81 (95\% CI: 1.02-3.20) of presenting malocclusion. Adjusting for covariates, orthodontic treatment need was higher for the youngest individuals who presented low socioeconomic status at age 6 , and who had untreated dental caries. 
Table 1

Distribution of 15-24 years old individuals in Montevideo, Uruguay, according to Dental Aesthetic Index (DAl) categories of malocclusion ( $\mathrm{n}=278$ ).

\begin{tabular}{|c|c|c|c|c|c|c|c|}
\hline Characteristic & $\begin{array}{c}\text { Total } \\
\%(95 \% \mathrm{Cl})\end{array}$ & $\begin{array}{c}\text { DAI } \\
\text { Mean } \\
\text { score }(\mathbf{s d})\end{array}$ & $\begin{array}{c}\text { Normal } \\
\text { condition } \\
(\leq 25)\end{array}$ & $\begin{array}{c}\text { Definitive } \\
(26-30)\end{array}$ & $\begin{array}{l}\text { Severe } \\
(31-35)\end{array}$ & $\begin{array}{c}\text { Very severe/ } \\
\text { Handicapping } \\
\text { ( } \geq 36)\end{array}$ & p-value * \\
\hline Sex & & & & & & & 0.14 \\
\hline Female & $50.8(44.4-57.2)$ & $25.24(7.67)$ & 60.1 & 20.1 & 8.6 & 11.2 & \\
\hline Male & $49.2(42.8-55.6)$ & $23.43(6.04)$ & 62.0 & 24.5 & 10.2 & 3.4 & \\
\hline Age group (years) & & & & & & & 0.95 \\
\hline $14-17$ & $32.7(27.0-39.1)$ & $25.78(6.56)$ & 50.5 & 30.2 & 10.7 & 8.5 & \\
\hline $18-21$ & 36.5 (30.4-43.0) & $25.01(7.32)$ & 62.1 & 18.9 & 9.9 & 9.9 & \\
\hline $22-24$ & $30.8(25.4-36.8)$ & $22.56(6.73)$ & 71.0 & 17.7 & 7.3 & 4.0 & \\
\hline Untreated dental caries & & & & & & & 0.01 \\
\hline Absent & $23.1(18.2-28.8)$ & $24.36(6.73)$ & 71.7 & 15.3 & 1.8 & 11.2 & \\
\hline Present & $76.9(71.2-81.8)$ & $24.71(6.85)$ & 57.8 & 24.5 & 11.7 & 6.0 & \\
\hline \multicolumn{8}{|c|}{ Socioeconomic status at the age of 6} \\
\hline High & $5.0(12.3-22.3)$ & $21.38(9.37)$ & 82.7 & 13.6 & - & 3.7 & \\
\hline Medium & $78.2(72.4-83.2)$ & $24.38(6.61)$ & 63.5 & 22.0 & 7.3 & 7.1 & \\
\hline Low & $16.7(2.9-8.5)$ & $25.86(7.86)$ & 57.3 & 23.8 & 6.6 & 12.3 & \\
\hline \multicolumn{8}{|l|}{ Mother's education at the age of 6} \\
\hline Elementary school or more & $68.7(62.2-74.6)$ & $23.83(6.54)$ & 67.5 & 20.4 & 6.5 & 5.6 & \\
\hline Less than elementary school & $31.3(25.4-37.8)$ & $25.70(7.75)$ & 53.9 & 25.8 & 9.7 & 10.6 & \\
\hline \multicolumn{8}{|l|}{ Current socioeconomic level } \\
\hline Low & $41.4(35.4-48.0)$ & $26.06(6.32)$ & 53.8 & 27.1 & 9.0 & 10.2 & \\
\hline Medium/High & $58.6(52.0-64.6)$ & $24.32(7.06)$ & 66.2 & 18.8 & 9.6 & 5.3 & \\
\hline \multicolumn{8}{|c|}{$\begin{array}{l}\text { Perceived socioeconomic trajectory } \\
\text { from the age of } 6 \text { to the age of } 15-24\end{array}$} \\
\hline Never poor & $80.7(75.0-85.4)$ & $24.23(6.87)$ & 64.6 & 21.3 & 7.1 & 7.0 & \\
\hline Poor-non poor & $10.8(7.3-15.8)$ & $25.04(8.61)$ & 69.5 & 10.9 & 4.5 & 15.1 & \\
\hline Non poor-poor & $2.5(1.2-5.2)$ & $23.00(6.48)$ & 69.2 & 26.7 & - & 4.1 & \\
\hline Always poor & $5.9(3.5-9.9)$ & $27.37(6.22)$ & 34.7 & 47.6 & 10.7 & 7.0 & \\
\hline Total & & & 63.6 & 20.6 & 8.2 & 7.6 & \\
\hline
\end{tabular}

95\% Cl: 95\% confidence interval; sd: standard deviation.

* Chi-squared test for heterogeneity adjusted for sampling design.

\section{Discussion}

This study assessed orthodontic treatment need using data from the first nationally representative oral health survey in Uruguay and two main findings should be highlighted. First, the prevalence of orthodontic treatment need in Montevideo was 36.4\%, which can be considered relatively high and which is similar to the prevalence found in the countryside of Uruguay (33.8\%) 23. Secondly, it was found that adolescents and young people from Montevideo that reported being poor or very poor at age 6 showed higher orthodontic treatment needs.

Only one study has investigated the effects of early life socioeconomic factors on malocclusion, but results showed no association with open bite, in a sample of 6 year-old children 30 . To our knowledge, this is the first study to assess the effect of early life socioeconomic status on orthodontic treatment need using DAI. In our study, the perceived socioeconomic status obtained could be a proxy for the true socioeconomic condition, and low socioeconomic status at age 6 was associated with orthodontic treatment need between the ages of 15-24. Although there is a possibility of memory bias, that is, current findings could be affected by poor recall, since it relied on adults' retrospective reports about their childhood, it is plausible that early life socioeconomic status affected malocclusions at later age (permanent dentition) because the exposure to factors that predispose to malocclusion during decidu- 


\section{Table 2}

Crude and adjusted ordinal logistic regression analyses of factors associated with presence of malocclusion among $15-24$ years-olds from Montevideo, Uguguay $(n=278)$.

\begin{tabular}{|c|c|c|c|c|}
\hline Variable & $\begin{array}{c}\text { Crude } \\
\text { OR }(95 \% \mathrm{CI})\end{array}$ & p-value & $\begin{array}{l}\text { Adjusted } \\
\text { OR }(95 \% \mathrm{CI})\end{array}$ & p-value \\
\hline Sex & & 0.47 & & 0.27 \\
\hline Female & 1.00 & & 1.00 & \\
\hline Male & $0.83(0.49-1.38)$ & & $0.73(0.42-1.28)$ & \\
\hline Age group (years) & & 0.01 & & 0.01 \\
\hline $14-17$ & 1.00 & & 1.00 & \\
\hline $18-21$ & $0.70(0.38-1.31)$ & & $0.69(0.34-1.38)$ & \\
\hline $22-24$ & $0.45(0.24-0.84)$ & & $0.40(0.19-0.81)$ & \\
\hline Untreated dental caries & & 0.08 & & 0.01 \\
\hline Absent & 1.00 & & 1.00 & \\
\hline Present & $1.49(0.96-2.32)$ & & $1.11(1.03-1.20)$ & \\
\hline Socioeconomic status at the age of 6 & & 0.12 & & 0.12 \\
\hline High & 1.00 & & 1.00 & \\
\hline Medium & $2.78(0.74-10.98)$ & & $4.44(0.97-20.31)$ & \\
\hline Low & $3.73(0.84-16.59)$ & & $5.52(1.06-28.62)$ & \\
\hline Mother's education at the age of 6 & & 0.04 & & \\
\hline Elementary school or more & 1.00 & & - & \\
\hline Less than elementary school & $1.81(1.02-3.20)$ & & & \\
\hline Current socioeconomic level & & 0.06 & - & \\
\hline High/Medium & 1.00 & & & \\
\hline Low & $1.63(0.97-2.74)$ & & & \\
\hline $\begin{array}{l}\text { Perceived socioeconomic trajectory from the age of } 6 \text { to the age } \\
\text { of } 15-24\end{array}$ & & 0.11 & - & \\
\hline Never poor & 1.00 & & & \\
\hline Poor-Non poor & $0.93(0.32-2.70)$ & & & \\
\hline Non poor-poor & $0.74(0.19-2.94)$ & & & \\
\hline Always poor & $2.36(1.09-5.11)$ & & & \\
\hline
\end{tabular}

95\% Cl: 95\% confidence interval; OR: odds ratio.

ous and mixed dentition can be influenced by socioeconomic conditions. Noteworthy, the association of early life characteristics and malocclusion should ideally be tested in a longitudinal design. Despite the limitations of a cross-sectional design, which limits causal relationships, reverse causation (malocclusion causing poverty at age of 6) seems unlikely. Furthermore, as we had different socioeconomic variables, collinearity may explain why some have lost their relation with the outcome.

The response rate achieved in the study can be considered high and sampling weights were corrected by age and sex to compensate for differential response rates. However, a limitation of this study is that the sample size was not calculated to test our main hypothesis, therefore, the power was low, increasing the probability of type II error. The implications of such error are related to the fact that some variables that were not statistically significant may be. We believe that, in spite of this limitations, the associations were adequately adjusted and not biased. A strength of this study is that the diagnostic methods recommended by the World Health Organization were employed (DAI and DMFT) 31. Both indexes are considered valid and reliable, therefore leading to a low level of measurement bias. DAI has four ordinal categories (normal/mild, definitive, severe, handicapping). Thus, ordinal logistic regression was used in the data analysis. An advantage of this procedure is that it does not require an arbitrary cut-off point, as does the ordinary logistic regression. Additional analyses 
(not shown) using DAI as a continuous variable also showed that socioeconomic status at the age of 6 was associated with higher scores after controlling for age, sex and dental caries.

Early-life environmental conditions can influence health in later life directly and indirectly through their influence on subsequent life course trajectories ${ }^{32}$. In the present study, the perceived socioeconomic trajectory from the age of 6 to the age of 15-24 was not associated with malocclusion severity after adjustments, although in bivariate analyses participants who were always poor had higher odds of having a DAI category worse than participants who were never poor. Thus, findings suggest that early life socioeconomic status affects malocclusion and this effect is not affected by socioeconomic characteristics in adulthood. It is know that some social determinants, such as the mother's employment status and the occupation of the head of the household are related to oral habits associated with malocclusion in primary dentition ${ }^{33}$. In addition, a recent cohort study has showed that malocclusion in the deciduous teeth at the age of 6 is a risk factor for orthodontic treatment need in the permanent dentition. However, in that study no association of socioeconomic status and malocclusion was observed and the authors emphasized the role of genetics, sucking habits, and dental caries as the main determinants of malocclusion 13 .

According to a previous study 16 , untreated dental caries was associated with orthodontic treatment need. This condition presents a strong association with socioeconomic factors and its presence, especially when caries is untreated or when a tooth is lost, predisposes to occlusal and space anomalies in mixed and permanent dentition. It is worth mentioning that dental caries can also occur due to the presence of malocclusion, since occlusal alterations can make it difficult for patients to maintain good oral hygiene and it results in increased plaque accumulation on teeth surfaces 34 . Although the cross-sectional design of this study limits cause-effect inference, it is expected that policies aiming to reduce the prevalence of dental caries may also decrease future orthodontic treatment need 35 .

Among demographic variables, only age was associated with the outcome. Older individuals had lower chances of malocclusions. It is possible that older individuals had received orthodontic treatment, which improved occlusion 36 . As a limitation, we could not control for previous orthodontic treatment. However, in Uruguay orthodontic treatment is not covered by public health services and such treatment in uncommon. Among individuals from the countryside, orthodontic treatment was the reason for the last dental visit for $4.1 \%$ of the individuals, while $88.2 \%$ had their last visit for other reasons and $7.7 \%$ had never visited a dentist 23 .

More importantly, representative studies on prevalence, as this study, are crucial to monitor trends in oral health, to evaluate levels of dental needs and to plan oral health policies 35 . In Uruguay, it is extremely important, because no previous nationwide epidemiological study is available. The index used for orthodontic treatment need (DAI) may be used as a screening tool to assist in prioritizing for orthodontic treatment need. Besides the orthodontic perspective, factors associated with the outcome were investigated. Considering that the aetiology of malocclusion has genetic and environmental components, the analysis of factors related to the causes of such alteration may be useful to help planning oral health policies, including adequate preventive measures. In conclusion, the present study showed a high prevalence of malocclusion and a potential relationship between socioeconomic position during the lifespan and the occurrence of malocclusion in adolescent and young adults in Uruguay, under a life-course approach. 


\section{Contributors}

M. L. Goettems, M. Ourens, S. Lorenzo and R. K. Celeste participated in the study conception, data analysis and wrote the manuscript. L. Cosetti participated in the study conception and wrote the manuscript. R. Álvarez-Vaz participated in the oral health survey and revised the manuscript.

\section{Acknowledgments}

Financial support for the conduct of the research was provided by the Sectoral Commission for Scientific Research of the University of the Republic.

\section{References}

1. Claudino D, Traebert J. Malocclusion, dental aesthetic self-perception and quality of life in a 18 to 21 year-old population: a cross section study. BMC Oral Health 2013; 13:1-6.

2. Ukra A, Foster Page LA, Thomson WM, Farella M, Tawse Smith A, Beck V. Impact of malocclusion on quality of life among New Zealand adolescents. N Z Dent J 2013; 109:18-23.

3. Peres KG, Peres MA, Araujo CL, Menezes AM, Hallal PC. Social and dental status along the life course and oral health impacts in adolescents: a population-based birth cohort. Health Qual Life Outcomes 2009; 7:95.

4. Feu D, Miguel JA, Celeste RK, Oliveira BH. Effect of orthodontic treatment on oral healthrelated quality of life. Angle Orthod 2013; 83:892-8.

5. Palomares NB, Celeste RK, Oliveira BH, Miguel JA. How does orthodontic treatment affect young adults' oral health-related quality of life? Am J Orthod Dentofacial Orthop 2012; 141:751-8.

6. Leighton BC. Aetiology of malocclusion of the teeth. Arch Dis Child 1991; 66:1011-2.

7. Aznar T, Galan AF, Marin I, Dominguez A. Dental arch diameters and relationships to oral habits. Angle Orthod 2006; 76:441-5.

8. Moimaz SA, Garbin AJ, Lima AM, Lolli LF, Saliba O, Garbin CA. Longitudinal study of habits leading to malocclusion development in childhood. BMC Oral Health 2014; 14:96.

9. Thomaz EB, Cangussu MC, Assis AM. Malocclusion and deleterious oral habits among adolescents in a developing area in northeastern Brazil. Braz Oral Res 2013; 27:62-9.

10. Hebling SR, Cortellazzi KL, Tagliaferro EP, Hebling E, Ambrosano GM, Meneghim MC, et al. Relationship between malocclusion and behavioral, demographic and socioeconomic variables: a cross-sectional study of 5-yearolds. J Clin Pediatr Dent 2008; 33:75-9.

11. Machado MCM, Assis KF, Oliveira FC, Ribeiro AQ, Araújo RM, Cury AF, et al. Determinants of the exclusive breastfeeding abandonment: psychosocial factors. Rev Saúde Pública 2014; 48:985-94.

12. Peres KG, Cascaes AM, Nascimento GG, Victora CG. Effect of breastfeeding on malocclusions: a systematic review and meta-analysis. Acta Paediatr 2015; 104:54-61.

13. Peres KG, Peres MA, Thomson WM, Broadbent J, Hallal PC, Menezes AB. Deciduousdentition malocclusion predicts orthodontic treatment needs later: findings from a population-based birth cohort study. Am J Orthod Dentofacial Orthop 2015; 147:492-8.

14. Ovsenik M, Farcnik FM, Korpar M, Verdenik I. Follow-up study of functional and morphological malocclusion trait changes from 3 to 12 years of age. Eur J Orthod 2007; 29:523-9. 
15. Silveira MF, Freire RS, Nepomuceno MO, Martins AMEdB, Marcopito LF. Severity of malocclusion in adolescents: populationalbased study in the north of Minas Gerais, Brazil. Rev Saúde Pública 2016; 50:11.

16. Frazao P, Narvai PC. Socio-environmental factors associated with dental occlusion in adolescents. Am J Orthod Dentofacial Orthop 2006; 129:809-16.

17. Celeste RK, Nadanovsky P. How much of the income inequality effect can be explained by public policy? Evidence from oral health in Brazil. Health Policy 2010; 97:250-8.

18. Germa A, Kaminski M, Nabet C. Impact of social and economic characteristics on orthodontic treatment among children and teenagers in France. Community Dent Oral Epidemiol 2010; 38:171-9.

19. Schuch HS, Peres KG, Do LG, Peres MA. Can socioeconomic trajectories during the life influence periodontal disease occurrence in adulthood? Hypotheses from a life-course perspective. Med Hypotheses 2015; 84:596-600.

20. Peres MA, Oliveira Latorre MR, Sheiham A, Peres KG, Barros FC, Hernandez PG, et al. Social and biological early life influences on severity of dental caries in children aged 6 years. Community Dent Oral Epidemiol 2005; 33:53-63.

21. Shivakumar KM, Chandu GN, Subba Reddy VV, Shafiulla MD. Prevalence of malocclusion and orthodontic treatment needs among middle and high school children of Davangere city, India by using Dental Aesthetic Index. J Indian Soc Pedod Prev Dent 2009; 27:211-8.

22. Page LA, Thomson WM, Quick AN. Changes in malocclusion over time in New Zealand adolescents. Aust Orthod J 2011; 27:169-75.

23. Ourens M, Celeste R, Hilgert JB, Orenzo S, Hugo FN, Alvarez R, et al. Prevalencia de maloclusiones en adolescentes y adultos jóvenes del interior del Uruguay. Relevamiento nacional de salud bucal 2010-20. Odontoestomatologia 2013; 15(n spe):47-57.

24. Lorenzo S, Alvarez R, Blanco S, Peres M. Primer relevamiento nacional de salud bucal en población joven y adulta uruguaya. Aspectos metodológicos. Odontoestomatologia 2013; 15(no spe):8-25.

25. Secretaria de Atenção à Saúde; Secretaria de Vigilância em Saúde, Ministério da Saúde. SB BRASIL 2010. Pesquisa Nacional de Saúde Bucal. Resultados principais. Brasília: Ministério da Saúde; 2012.
26. World Health Organization. Oral health surveys: basic methods. 4th Ed. Geneva: World Health Organization; 1997.

27. Estioko LJ, Wright FA, Morgan MV. Orthodontic treatment need of secondary schoolchildren in Heidelberg, Victoria: an epidemiologic study using the Dental Aesthetic Index. Community Dent Health 1994; 11:147-51.

28. Departamento de Sociología, Facultad de Ciencias Sociales, Universidad de la República. Validación Nacional del Índice de Nivel Socio Económico para estudios de mercado y opinión pública. Montevideo: Universidad de la República; 2006.

29. Fernández A, Perera M. Índice de Niveles Socio-Económicos (INSE). Informe final. Montevideo: CPA-Ferrere; 2003.

30. Peres KG, Oliveira Latorre MR, Sheiham A, Peres MA, Victora CG, Barros FC. Social and biological early life influences on the prevalence of open bite in Brazilian 6-year-olds. Int J Paediatr Dent 2007; 17:41-9.

31. World Health Organization. Encuestas de salud bucodental: métodos básicos. 4th Ed. Geneva: World Health Organization; 1997.

32. Frijters P, Hatton TJ, Martin RM, Shields MA. Childhood economic conditions and length of life: evidence from the UK Boyd Orr cohort, 1937-2005. J Health Econ 2010; 29:39-47.

33. Tomita NE, Sheiham A, Bijella VT, Franco LJ. Relação entre determinantes socioeconômicos e hábitos bucais de risco para más-oclusões em pré-escolares. Pesq Odontol Bras 2000; 14:169-75.

34. Gaikwad SS, Gheware A, Kamatagi L, Pasumarthy S, Pawar V, Fatangare M. Dental caries and its relationship to malocclusion in permanent dentition among 12-15 year old school going children. J Int Oral Health 2014; 6:2730.

35. Nalcaci R, Demirer S, Ozturk F, Altan BA, Sokucu O, Bostanci V. The relationship of orthodontic treatment need with periodontal status, dental caries, and sociodemographic factors. ScientificWorldJournal 2012; 2012:498012.

36. Cunha-Cruz J, Miguel JA. Orthodontic treatment needs may be associated with unfavorable socioeconomic conditions. J Evid Based Dent Pract 2007; 7:141-3. 


\section{Resumen}

El objetivo de este estudio es estimar el tratamiento de ortodoncia que necesitan jóvenes entre 15 y 24 años en Montevideo, Uruguay, y la asociación de los rasgos oclusores con factores demográficos, clínicos y socioeconómicos, considerando el ciclo vital. Se trata de un estudio transversal que maneja datos de la Primera Encuesta Nacional de Salud Bucal en Uruguay. Se utilizó un procedimiento de análisis de clúster en dos fases para seleccionar una muestra de 278 personas en Montevideo. Se realizaron entrevistas domiciliarias y exámenes bucales por parte de seis dentistas. Se usaron también datos de índices de cirugías estéticas (DAI) y del número de dientes cariados, perdidos y obturados (DCPO), con el fin de evaluar el tratamiento necesario ortodóntico y las caries dentales, respectivamente. La primera infancia y la situación socioeconómica actual fueron factores que se obtuvieron de la entrevista. Se usó una regresión logística ordinaria para modelar el índice DAI. La prevalencia de la maloclusión definitiva fue de un $20,6 \%$, seguida por la severa $(8,2 \%)$ y la muy severa (7,6\%). En el análisis ajustado, las personas que no se habian tratado las caries dentales $(O R=$ 1,11; IC95\%: 1,03-1,20), y quienes informaron de un nivel socioeconómico bajo a los 6 años de edad $(O R=5,52$; IC95\%: 1,06-28,62), tenían una mayor probabilidad de sufrir un caso de maloclusión. La posición socioeconómica actual no se asoció con el tratamiento ortodóntico necesitado. Las personas con 22-24 años (OR = 1,59; IC95\%: 1,05-2,41) tenían una probabilidad más baja que aquellos con una edad entre 14-17. Este estudio muestra que el tratamiento ortodóntico necesario es relativamente alto en adolescentes uruguayos y adultos jóvenes. Hay una relación potencial entre el estatus socioeconómico en la primera infancia y la ocurrencia de maloclusión en adolescentes y jóvenes adultos desde una perspectiva del ciclo vital.

Maloclusión; Caries Dental; Odontología

\section{Resumo}

O estudo teve como objetivo estimar a necessidade de tratamento ortodôntico na faixa etária de 15 a 24 anos em Montevideo, Uruguai, e a associação entre características oclusais e fatores demográficos, clínicos e socioeconômicos, com base na trajetória de vida. Foi realizado um estudo transversal, utilizando dados da 1a Pesquisa Nacional de Saúde Oral do Uruguai. Foi utilizado um procedimento de cluster em dois estágios para selecionar uma amostra de 278 indivíduos em Montevideo. Entrevistas domiciliares e exames odontológicos foram realizados por seis odontólogos. O indice de estética dentária (DAI) e o índice de dentes cariados, perdidos e obturados (DMFT/CPOD) foram usados para avaliar a necessidade de tratamento ortodôntico e de cárie dentária, respectivamente. Foram obtidos dados socioeconômicos da primeira infância e atuais, a partir de entrevistas. Foi utilizada a regressão logística ordinal para modelar o índice de estética dentária. A prevalência de oclusopatia definida era $20,6 \%$, seguida pela forma grave $(8,2 \%)$ e muito grave $(7,6 \%)$. Na análise ajustada, indivíduos com cárie dentária não tratada $(O R=1,11$; IC95\%: 1,03-1,20) e aqueles de nível socioeconômico mais baixo aos 6 anos de idade $(O R=5,52$; IC95\%: 1,06-28,62) mostravam chances mais altas de apresentar oclusopatia mais grave. O nível socioeconômico atual não mostrou associação com necessidade de tratamento ortodôntico. Os indivíduos na faixa etária de 22-24 anos (OR = 1,59; IC95\%: 1,05-2,41) mostraram probabilidade menor de oclusopatia quando comparados com a faixa etária de 14-17 anos. O estudo mostra que a necessidade de tratamento ortodôntico é relativamente alta entre adolescentes e adultos jovens uruguaios. De acordo com a abordagem de trajetória de vida, existe uma relação potencial entre nível socioeconômico na primeira infância e oclusopatia em adolescentes e adultos jovens.

Má Oclusão; Cárie Dentária; Odontologia
Submitted on 27/Mar/2017

Final version resubmitted on 14/Jun/2017

Aproved on 27/Jun/2017 